\title{
THE URINARY EXCRETION OF HISTAMINE IN SCHIZOPHRENIA
}

\author{
BY \\ J. ADAM and R. G. MITCHELL \\ From Queen's College, University of St. Andrews, and Westgreen Hospital, Dundee
}

It has frequently been observed that patients with schizophrenia are more tolerant of the effects of histamine than are normal people (Hill, 1940; Hoch, 1952; Lucy, 1954; Rouleau, Delâge, Bouchard, Coulombe, and Nadeau, 1954). For example, Lucy (1954) gave $28 \mathrm{mg}$. of histamine base to a schizophrenic patient-a dose four times as great as any previously recorded-and there were no side-effects other than a fall in blood pressure. This increased tolerance may be related to the general lack of responsiveness to biochemical stimuli shown by schizophrenics or it may indicate some abnormality of the metabolism of histamine. Adam (1950) concluded that information about the role of histamine in the pathogenesis of disease might be obtained by investigating the excretion of free histamine in the urine. The present work was undertaken to determine whether an abnormal metabolism of histamine in schizophrenia could be demonstrated by this means.

\section{Methods and Procedure}

Free histamine was extracted from urine by a chromatographic method in which histamine is adsorbed on a cation exchange column and subsequently eluted and dried (Roberts and Adam, 1950). The extracted histamine is concentrated by taking it up in a smaller volume than that of the original urine, and assayed biologically on a strip of guinea-pig's ileum suspended in a bath of atropinized Tyrode solution. In preliminary tests using this method, $63.4 \% \pm 2.8$ of histamine added to urine was recovered, a rate similar to that of $67 \% \pm 1 \cdot 1$ reported by Roberts and Adam (1950). This recovery rate of approximately two-thirds is a characteristic of the method and a correction factor can be applied if necessary. All the values for histamine in this paper are uncorrected and are expressed in terms of the free base, unless otherwise stated.

A modified form of the histamine excretion test described by one of us (Mitchell, 1956a) was used in the investigation. The subject fasted for at least 10 hours before the test began, and throughout its duration, only water being allowed by mouth. At 8 a.m. the bladder was emptied and the urine discarded. At 10 a.m. urine was passed into a bottle containing a few millilitres of
2N HC1. During the next two hours, histamine acid phosphate was injected subcutaneously, the total dose of $20 \mu \mathrm{g}$. per $\mathrm{kg}$. of body weight being divided into four equal injections, which were given at intervals of half an hour (at 10, 10.30, 11, and 11.30 a.m.). At 12 noon, urine was again collected, thus giving two two-hour samples for the extraction of histamine.

Sixteen male patients with schizophrenia were tested during the investigation. Their ages ranged from 18 to 54 years and the duration of the illness was from two to 19 years. All had been under observation for at least two years and in every case several psychiatrists had concurred in the diagnosis. The group comprised patients with hebephrenic, catatonic, paranoid, and simple types of schizophrenia. All showed the typical schizophrenie thought disorder and at some time all had shown the more florid signs and symptoms, such as delusionsohallucinations, excitement, and stupor. At the time of the investigation, however, some were listless, apathetio융 and asocial.

The modified histamine excretion test outlined aboke⿳亠二口犬 was carried out on nine of the patients and on nine health men, aged from 31 to 46 years. It was noteworthy that the patients made no complaint and only local wealing was observed as a result of the histamine injections, whereas the healthy men experienced headache and flushing.

In a second series of experiments, the excretion test was carried out on five more of the patients with schizophrenia, using a total dose of histamine acid phosphate of $10 \mu \mathrm{g}$. per $\mathrm{kg}$. instead of $20 \mu \mathrm{g}$. per $\mathrm{kg}$. as used in the first series. Half an hour before the first injection (at 9.30 a.m.) the patient was given an oral dose of the histaminase-inhibiting drug, aminoguanidine bicarbonate, $10 \mathrm{mg}$. being given per $\mathrm{kg}$. of body weight.

Finally, histamine excretion tests were made on two further patients but instead of four injections of histamine during the second two-hour period, a single injection of $2.5 \mathrm{mg}$. of histamine acid phosphate was given at 10 a.m. in each case, this dose representing $47 \mu \mathrm{g}$. and $34 \mu \mathrm{g}$. per kg. respectively.

In every instance, extraction of free histamine from the urine was completed on the day the clinical test was carried out. To eliminate any possible bias, one of us $N$ conducted the clinical tests and did not know the results of the assays until the investigation was completed; $N$ the other extracted and assayed the histamine without knowing the source of the urine sample. 
TABLE I

EFFECT OF SUBCUTANEOUS INJECTION OF HISTAMINE ACID PHOSPHATE ON EXCRETION OF FREE HISTAMINE IN URINE OF SCHIZOPHRENICS AND OF HEALTHY MEN

\begin{tabular}{|c|c|c|c|c|}
\hline \multirow{2}{*}{ Subjects } & \multirow{2}{*}{$\begin{array}{l}\text { Total Dose of Hista- } \\
\text { mine Acid Phosphate } \\
\text { Injected during Period } \\
\text { II (mg.) }\end{array}$} & \multicolumn{2}{|c|}{ Free Histamine in Urine ( $\mu \mathrm{g})}$. & \multirow{2}{*}{$\begin{array}{l}\text { Extra Free Histamine Ex- } \\
\text { creted in Period II as } \\
\text { Percentage of Dose In- } \\
\text { jected }\end{array}$} \\
\hline & & $\begin{array}{l}\text { Period I } \\
\text { 8-10 a.m. }\end{array}$ & $\begin{array}{c}\text { Period II } \\
10 \text { a.m. }-12 \text { noon }\end{array}$ & \\
\hline $\begin{array}{c}\text { Schizophrenics } \\
1 \\
2 \\
3 \\
4 \\
5 \\
6 \\
7 \\
8 \\
9\end{array}$ & $\begin{array}{l}1 \cdot 40 \\
1 \cdot 30 \\
1 \cdot 15 \\
1 \cdot 25 \\
1 \cdot 70 \\
1 \cdot 12 \\
1 \cdot 06 \\
1 \cdot 25 \\
1 \cdot 29\end{array}$ & $\begin{array}{l}0.58 \\
0.44 \\
0.51 \\
1 \cdot 22 \\
0.46 \\
0.88 \\
0.95 \\
0.55 \\
1 \cdot 24\end{array}$ & $\begin{array}{l}2 \cdot 75 \\
2 \cdot 10 \\
3 \cdot 71 \\
5 \cdot 43 \\
3 \cdot 44 \\
3 \cdot 29 \\
1 \cdot 84 \\
4 \cdot 13 \\
4 \cdot 50\end{array}$ & $\begin{array}{l}0.68 \\
0.56 \\
1 \cdot 21 \\
1 \cdot 47 \\
0 \cdot 76 \\
0.94 \\
0 \cdot 37 \\
1 \cdot 25 \\
1 \cdot 10\end{array}$ \\
\hline Mean & $1 \cdot 28$ & $0 \cdot 76$ & $3 \cdot 47$ & 0.93 \\
\hline $\begin{array}{c}\text { Healthy men } \\
1 \\
2 \\
3 \\
3 \\
4 \\
5 \\
6 \\
7 \\
8 \\
9\end{array}$ & $\begin{array}{l}1 \cdot 30 \\
1.66 \\
1 \cdot 44 \\
1 \cdot 40 \\
1.08 \\
1 \cdot 10 \\
1 \cdot 30 \\
1 \cdot 06 \\
1 \cdot 41\end{array}$ & $\begin{array}{l}1 \cdot 16 \\
0 \cdot 81 \\
1 \cdot 35 \\
0 \cdot 72 \\
0 \cdot 43 \\
1 \cdot 26 \\
0 \cdot 44 \\
0 \cdot 52 \\
0 \cdot 72\end{array}$ & $\begin{array}{l}3 \cdot 52 \\
4 \cdot 20 \\
7 \cdot 14 \\
2 \cdot 87 \\
2 \cdot 16 \\
4 \cdot 56 \\
3 \cdot 30 \\
2 \cdot 50 \\
6 \cdot 50\end{array}$ & $\begin{array}{l}0 \cdot 79 \\
0.89 \\
1 \cdot 75 \\
0.67 \\
0 \cdot 70 \\
1 \cdot 31 \\
0.96 \\
0.82 \\
1 \cdot 79\end{array}$ \\
\hline Mean & $1 \cdot 31$ & 0.82 & $4 \cdot 08$ & $1 \cdot 08$ \\
\hline
\end{tabular}

\section{Results}

The results of the first series of experiments are recorded in Table I. It can be seen that there is no significant difference between the mean doses of histamine acid phosphate for the two groups, indicating that the mean body weight of the nine schizophrenic patients was virtually the same as that of the nine healthy men. This close correspondence was fortuitous, because no attempt was made to match the subjects by weight, and selection was made on no other basis than clinical suitability in the case of the patients and convenience in the case of the healthy volunteers. The mean amount of free histamine excreted by the patients during the first period of two hours was $0.76 \mu \mathrm{g}$., the range being from 0.44 to $1 \cdot 24 \mu \mathrm{g}$. The amounts excreted by the healthy men ranged from 0.43 to $1.35 \mu \mathrm{g}$., the mean value being $0.82 \mu \mathrm{g}$. There is no significant difference between these two series and the ranges of values are similar to those found previously for the basal excretion of free histamine by healthy men (Mitchell and Code, 1954; Mitchell, 1956a).

The amount of extra free histamine excreted during period II as a result of the injections was estimated by subtracting the value for period I from that for period II. The mean amount excreted by the schizophrenic patients was $2 \cdot 71 \mu \mathrm{g}$., while that excreted by the healthy men was $3.28 \mu \mathrm{g}$. When the values are multiplied by $\frac{100}{63 \cdot 4}$ (to correct for loss by the method) and converted to terms of histamine acid phosphate (assuming that this contains 36.16\% of the base) they can be expressed as a percentage of the total dose of histamine acid phosphate injected. Calculated in this way, the mean percentage of the dose excreted by the patients was $0.93 \%$ and by the healthy men was $1.08 \%$. The difference between these mean values is not statistically significant $(P=0.4)$ nor do they differ significantly from the mean value of $0.96 \%$ found in 12

TABLE II

EFFECT OF DOSES OF AMINOGUANIDINE BICARBONATE ON EXCRETION OF HISTAMINE INJECTED SUBCUTANEOUSLY INTO SCHIZOPHRENICS

\begin{tabular}{|c|c|c|c|c|c|}
\hline \multirow[b]{2}{*}{ Patient } & \multirow{2}{*}{$\begin{array}{l}\text { Total Dose of Hista- } \\
\text { mine Acid Phosphate } \\
\text { In jected during } \\
\text { Period II } \\
\text { (mg.) }\end{array}$} & \multirow{2}{*}{$\begin{array}{c}\text { Dose of Amino- } \\
\text { guanidine Given Orally } \\
\text { at } 9.30 \\
\text { (mg.) }\end{array}$} & \multicolumn{2}{|c|}{ Free Histamine in Urine ( $\mu \mathrm{g})}$. & \multirow{2}{*}{$\begin{array}{l}\text { Extra Free Histamine Ex- } \\
\text { creted in Period II as } \\
\text { Percentage of Dose In- } \\
\quad \text { jected }\end{array}$} \\
\hline & & & $\begin{array}{l}\text { Period I } \\
\text { 8-10 a.m. }\end{array}$ & $\begin{array}{c}\text { Period II } \\
10 \text { a.m. }-12 \text { noon }\end{array}$ & \\
\hline $\begin{array}{l}10 \\
11 \\
12 \\
13 \\
14\end{array}$ & $\begin{array}{l}0.57 \\
0.53 \\
0.52 \\
0.92 \\
0.53\end{array}$ & $\begin{array}{l}570 \\
530 \\
520 \\
920 \\
530\end{array}$ & $\begin{array}{l}0 \cdot 48 \\
0 \cdot 75 \\
0 \cdot 22 \\
0 \cdot 56 \\
1 \cdot 00\end{array}$ & $\begin{array}{l}4 \cdot 74 \\
4 \cdot 15 \\
2 \cdot 20 \\
5 \cdot 82 \\
4 \cdot 90\end{array}$ & $\begin{array}{l}3 \cdot 26 \\
2 \cdot 80 \\
1 \cdot 64 \\
2 \cdot 49 \\
3 \cdot 21\end{array}$ \\
\hline Mean & 0.61 & 614 & 0.60 & $4 \cdot 36$ & $2 \cdot 68$ \\
\hline
\end{tabular}


histamine excretion tests on other healthy men, with doses of histamine acid phosphate ranging from 5 to $20 \mu \mathrm{g}$. per $\mathrm{kg}$. (Mitchell, 1956a).

When the histamine was injected as a large single dose the proportion excreted was essentially the same. The two patients given $2.5 \mathrm{mg}$. of histamine acid phosphate excreted 7.23 and $4.77 \mu \mathrm{g}$. of extra free histamine during period II, representing respectively $1.26 \%$ and $0.83 \%$ of the dose injected.

The results of the experiments with aminoguanidine are shown in Table II. When aminoguanidine was given before the histamine injections, the mean percentage of the dose excreted as free histamine was 2.68 , a mean value similar to that of $3.05 \%$ found in similar tests on healthy men (Mitchell, 1956b).

\section{Discussion}

The physiopathology of the schizophrenias has been intensively studied over many years in the search for an organic basis for these disorders. The high incidence during adolescence and at the menopause suggests that the endocrine system is involved, but, although the association of endocrine disease and schizophrenia has often been reported, no consistent relationship has been established. Therapeutic administration of every conceivable gland preparation has been tried without success and many biologically active substances, such as acetyl choline and histamine, have been used with conflicting results.

Metabolic studies have been similarly unproductive and a review by Hoskins (1946) of his own and other authors' work in this field revealed very little of aetiological significance. A notable exception is the demonstration by Gjessing (1935, 1947) that there is a disturbance of nitrogen metabolism in periodic catatonia. This condition, however, probably accounts for less than $2 \%$ of all cases of schizophrenia. The only constant finding has been that the schizophrenic patient is less responsive to stimuli such as heat, cold, thyroid extract, insulin, and adrenaline. In the case of histamine the lack of response has been described as "staggering" (Lucy, 1954), tolerance of doses in excess of $20 \mathrm{mg}$. of histamine base being commonplace. Lucy's work shows that this abnormal tolerance of histamine increases with the duration of the illness, and he concludes that on the available evidence it appears to be a non-specific reaction.

Our experiments indicate that the pattern of histamine metabolism in schizophrenia does not differ from the normal. The basal excretion of free 으 histamine in the urine of the schizophrenic men $\underset{\mathbb{Q}}{Z}$ was similar to that of the healthy men, indicating that the usual amounts of histamine were being liberated from the tissues into the blood stream. The schizophrenic patients excreted injected hista- 0 mine normally, and the fact that the proportion of the dose excreted increased by the expected amount $\stackrel{\rho}{\stackrel{9}{?}}$. when histaminase was inhibited by aminoguanidine

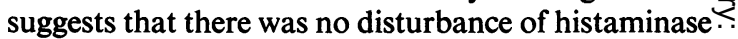

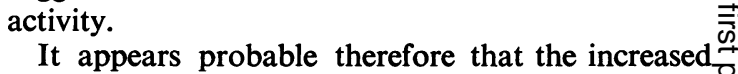
tolerance of histamine shown in schizophrenia is $\frac{C}{\sigma}$ simply a manifestation of a general lack of responsive- $\frac{\bar{c}}{\bar{c}}$ ness rather than a specific metabolic defect.

\section{Summary}

Free histamine was measured in the urine of $16 . \vec{\circ}$ men with schizophrenia, before and after the sub- $\vec{\omega}$ cutaneous injection of histamine.

Values for the basal excretion of free histamine and the percentage of the injected dose which was? excreted did not differ significantly from those ${ }^{\circ}$ recorded for healthy men.

When the histaminase-inhibiting drug, aminge $\overrightarrow{\vec{A}}$ guanidine, was given before injecting the histaminfor, $\overrightarrow{+}$ the mean percentage of the dose excreted increased from 0.93 to 2.68 , a change comparable with that occurring in healthy men.

No abnormality of histamine metabolism has therefore been found in schizophrenia, and $\overrightarrow{0} \overrightarrow{0}$ appears that the increased tolerance of histaminge. shown by schizophrenics is part of a general lack of tissue responsiveness.

Thanks are due to Dr. A. A. Bell, Physician Super-®ँ intendent of Westgreen Hospital, for permission to $\mathbb{O}$ investigate patients under his care, and to Professor $\stackrel{2}{\Rightarrow}$ R. B. Hunter for providing facilities in the Departmento of Pharmacology, Queen's College.

\section{REFERENCES}

Adam, H. M. (1950). Quart. J. exp. Physiol., 35, 281. Adam, H. M. (1950). Quart. J. exp. Physiol., 35, 281. Gjessing, R. (1935). Arch. Psychiat. Nervenkr., 104, 355.

Hill, H. (1940). The Histamine and Insulin Treatment of Schizophrenia' and Other Mental Diseases. Baillière, Tindall, and Cox, London.

Hoch, P. H. (1952). Amer. J. Psychiat., 109, 229.

Hoskins, R. G. (1946). The Biology of Schizophrenia. Norton, New York.

Lucy, J. D. (1954). A.M.A. Arch. Neurol. Psychiat., 71, 629.

Mitchell, R. G. (1956a). Brit. J. Pharmacol., 11, 462.

Mitchell, R. G. (1956a). Brit.

, and Code, C.' F. (1954), J. appl. Physiol., 6, 387.

Roberts, M., and Adam, H. M. (1950). Brit. J. Pharmacol., 5, 526.

Rouleau, Y., Delâge, J., Bouchard, M., Coulombe, M., and Nadeau, G. (1954). Laval méd., 19, 13. 